\title{
Wheat Productivity: Role of Farmers' Nutritional Status
}

\author{
Zia ud Din ${ }^{1 *}$, Parvez Iqbal Paracha ${ }^{1}$, Zahoor ul Haq ${ }^{2}$, Zahoor Ahmad ${ }^{1}$, \\ Zara Khan ${ }^{1}$, Muhammad Asif ${ }^{3}$
}

${ }^{I}$ Department of Human Nutrition, The University of Agriculture, Peshawar, Pakistan

${ }^{2}$ Department of Management Sciences, Abdul Wali Khan University, Mardan, Pakistan

${ }^{3}$ Pakistan Agricultural Research Council, Islamabad, Pakistan

A R T I C LE IN F O

Article history:

Received 02 May 2016

Accepted 01 August 2016

Available online, ISSN: $2148-127 \mathrm{X}$

Keywords:

Wheat productivity

Farmers' Nutritional Status

Pakistan

Small scale farms

\author{
"Corresponding Author: \\ E-mail: ziaud.din@aup.edu.pk
}

A B S T R A C T

This follow-up study was carried out to investigate association of wheat productivity with the nutritional status of farmers in an agricultural area of North West Pakistan. A total of 1200 small scale farmers were randomly recruited and screened for nutrition status. Total of 226 farmers were found malnourished. An equal number of well-nourished farmers were randomly selected; detailed data on wheat yield and relevant confounding factors were collected interviewing groups. Multivariate linear regression analysis was performed to identify factors in relation to wheat yield. Comparing to well-nourished, malnourished farmers were more likely to report less wheat yield. Agricultural predictors that independently and significantly explained variation in wheat production included crop rotation, sowing time, and per acre agricultural inputs. Farmers' nutritional status; and dietary patterns further increased variance in wheat yield. The study findings reaffirmed the importance of farmers' nutritional status in predicting wheat yield.

\section{Introduction}

Agriculture is the backbone of Pakistan's economy, contributing $45 \%$ to the country's employment and provides input to the agro-based industries. The livestock sector accounts for $55.1 \%$ of the agriculture value added and $11.5 \%$ of the GDP during 2010-11 (Pakistan Economic Survey, 2010-2011). The National Nutrition Survey of Pakistan (National Nutrition Survey, 2011) shows that $53.6 \%$ of the household heads are farmers, of which $61.6 \%$ belong to the rural population. These facts and figures show the dynamic role of farmers in the national economy.

Wheat, being both a staple and a cash crop, has very large area and tonnage among all food crops in Pakistan. It occupies a central position in all agricultural policies. Wheat productivity has increased in the past few decades in Pakistan because of several factors. Deployment of high yielding cultivars, increased fertilizer use, improved access to water and betterment in crop protection measures played a significant role in overall agricultural productivity. However, wheat production in Pakistan is still lower than other neighboring countries like China and Iran. Similarly, high fluctuation in wheat yield has been observed in Pakistan; wheat production decreased in 2014-15 by $2 \%$ as compared to 2013-14 (Pakistan Economic Survey 2014-2015). These gaps in production as well as fluctuations in yield reflect the existence of factors of various natures, directly or indirectly influencing agricultural productivity. Quantitative analysis of all possible determinants of agricultural productivity is therefore important to improve and sustain farm yield.

Globally, general nutrition status had improved in recent decades but malnutrition is still widespread particularly in developing countries. It is a wellestablished fact that there is a synergistic relationship between nutritional status and physical performance, cognitive and agricultural productivity (Croppenstedt and Muller, 2000). Similarly, studies on nutritional intervention in the rural settings have shown a significant link between intervention and agricultural outputs (Hoddinott et al., 2008; Loureiro, 2009; Ulimwengu, 2009; Badiane and Ulimwengu, 2009). Improvement of nutritional status has been strongly linked to behavioral and physical performance; thus farmers deserve preferential treatment because of their multiple responsibilities in agricultural and social sectors. Keeping in view important role of farming community in national income growth, present research project was designed to assess the nutritional status of farmers and its link with wheat productivity among small scale farmers in the North Western province of Khyber Pakhtunkhwa, Pakistan. 


\section{Materials and Methods}

\section{Study Location}

Current project was limited to farmers' nutritional status in association with agricultural productivity. The study aimed to find out the interaction of various factors (demographic, socioeconomic, agricultural characteristics and nutritional status) that may influence farm outputs. The study was conducted in District Mardan, located in North West Pakistan. Study area is largely an agricultural area and is known for its contribution to the green basket of the country. It has a well-established irrigation system and thus considered as the best agricultural area in the country. The soil of the area is fertile and very suitable for cultivation of major crops such as wheat, maize, sugarcane and tobacco. Beside these major crops, other important crops grown in this zone include rapeseed, mustard, fruits and vegetables.

\section{Sampling Method and Sample Size}

Total of 1200 farmers were selected using two-stage cluster sampling method. In the first stage, rural units along with their estimated number of farming households were selected randomly with probability - proportional to size technique. Once the units were selected, farmers were randomly selected. Inclusion criteria to select farmers was those having age $>20$ years, actively involved in farming activities and free from any chronic and infectious diseases. Farmers were enrolled in the study after getting their formal consent. Ethical approval for the study was obtained from the Directorate of Advanced Studies \& Research of the University of Agriculture, PeshawarPakistan.

\section{Farmers' Screening for Nutritional Status}

Nutrition statuses of the farmers $(n=1200)$ were assessed by taking their anthropometric measurements and blood hemoglobin level. Anthropometric measurements included weight and height. Weight was recorded in light, indoor clothing using the calibrated and standardized digital scale to the nearest 0.1 kilogram. The height was measured to the nearest $0.1 \mathrm{~cm}$. These both values were used to calculate body mass index (BMI) of the farmers. Hemoglobin $(\mathrm{Hb})$ concentration in the whole blood of farmers was determined using Hemocue (Chen and Seidl-Friedman, 1988).

Farmers having BMI $<18.5$ and / or blood Hb level < $13 \mathrm{~g} / \mathrm{dl}$ were considered at the risk of malnutrition. Based on baseline screening data, farmers at the risk of nutrition deficiency were identified as malnourished. Among the screened farmers, total of 226 (19\%) farmers were found malnourished. An equal number of control group $(n=226)$, being matched in other characteristics was randomly selected from the healthy farmers. These farmers were labelled as well-nourished and treated as control for comparison of various characteristics in statistical analysis.

\section{Data Collection}

All of the farmers (total=452; malnourished: 226 and well-nourished: 226) were re-contacted to collect detailed data on their socio-demographic, agricultural characteristics and dietary intake using standardized questionnaires.

Socio-demographic data were collected from each farmer by means of a pretested questionnaire. Sociodemographic factors could have confounding effect on the outcomes of interest. Similarly, data on various agricultural characteristics was collected using standardized questionnaires; these included farm size and occupation status (either the farmer occupied farm as owner, tenant or both), duration of agricultural practices, usual daily working hours in the farm, agricultural practices (such as crop rotation, intercropping, sowing time), weather status during the last major crop, seed types (i.e. certified or traditional), agricultural inputs per acre' used for major crops in term of quantity and cost, and productivity of the last major crops (wheat, maize, sugarcane and / or tobacco).

Dietary statuses of the farmers were assessed using pretested food frequency questionnaire (FFQ). The FFQ included all locally consumed food items and beverages. The participants were asked to recall the number of times each food item was consumed per day, week and month. Farmer who consumed food items less than 4 days a month were considered as 'rare/never' consumption of the food item.

\section{Statistical Analysis}

Data on the recent previously grown major crops was collected thoroughly; among these crops, data on wheat productivity and required relevant parameters was available on $434(96 \%)$ farmers. Data was entered into SPSS software (version 16) for Windows. Significance level was set as $\mathrm{P}<0.05$. Initial descriptive statistics were carried out to check the data for errors. Exploring the data by descriptive statistics helped to determine appropriate statistical techniques for data analysis. The data were checked for normalization using histograms. Following assurance of the normality of distribution (Shapiro-Wilk test and Kolmogorov-Smirnov test) and the homogeneity of variances (Levene's test), the data were analysed.

Using data from FFQ, farmers' dietary pattern (nutrient-rich and energy dense) were estimated. Based on similar nutrients profile, food items listed in the FFQ were grouped into 20 food groups. Two major dietary patterns, nutrient-rich (characterized by nutrients dense food items) and energy dense (characterized by energy dense food items) were identified based on the frequency of consumption of each of the 20 food groups using factor analysis. Data adequacy and possibility to perform factor analysis were assessed using the Kaiser-Meyer-Olkin Measure of Sampling Adequacy (KMO) (Kim and Mueller, 1978) and Bartlett Test of Sphericity (BTS) (Bartlett, 1950). 
A high KMO (maximum 1.0; minimum acceptable $0.5)$ indicates that data are likely to factor well since correlations between pairs of variables can be explained by the other variables. The factor analysis model was appropriate (KMO: 0.89; BTS showed a $\mathrm{P}<0.001)$. A correlation matrix was then constructed. Correlation coefficients were analyzed by principal component analysis (PCA) and subsequent rotation according to the standard varimax criterion. Two interpretable factors were retained based on the Scree test. Food groups with factor loadings $>0.30$ were retained in the patterns identified. Standardized factor score coefficients (mean \pm standard deviation, SD: $0 \pm 1$ ) were estimated by regression after PCA and saved for each dietary pattern. Dietary patterns were labeled based on interpretability and characteristics of the items retained in each pattern. These two variables were used to further generate two categorical variables; indicating farmers with 'nutrient-rich' and 'energy dense' dietary patterns. Variables showing the two dietary patterns were merged to generate a third variable indicating number of farmers with either 'nutrient-rich' or 'energy dense' dietary patterns; 65 (14\%) farmers were excluded because they were falling in both categories.

Pearson product-moment correlation coefficient was used to assess correlation among the variables. The Pointbiserial correlation was used in the situation where one variable was continuous and the other was dichotomous. An independent t-test was used to determine whether there was a statistically significant difference in nutritional and agricultural characteristics between the malnourished and well-nourished groups. Pearson Chisquare statistic was used to test the association of categorical variables with farmers' groups.

Multivariate linear regression analysis was performed to assess the individual impact of independent variables (socio-demographic; agricultural characteristics and inputs; and farmers' nutritional and dietary status) on 'per acre wheat productivity', using a hierarchical model in which variables were entered in blocks. Of the explanatory variables, farmers' age; years of formal education; farming experience; seed application rate; application of organic and synthetic fertilizers; total rented labour days on the farm; number of total irrigation; and total ploughing hours were treated as continuous variables and all others as dichotomous variables except for farm occupation status, which was treated as a dummy. Two dummy variables identifying the three levels of farm occupation statuses were generated. Variable on 'farm holding size (acre)' was converted into categorical one to represent two levels of farm size $(<4$ acre and $>4$ acres). A test of multicollinearity of the independent variables based on tolerance and the variance inflation factor (VIF) was first performed. Tolerance > 0.1 and $\mathrm{VIF}<10$ indicate no serious collinearity (Kutner et al. 2004). All variables with $\mathrm{p}<0.20$ on bivariate analysis were selected for inclusion in the regression analysis model. To examine the predictive relationship of farmers' nutritional status with wheat productivity, controlled variables were entered in the first three blocks while variables indicating farmers' nutritional status were entered in the final model. Block 1 included farmers' socio-demographic characteristics; block 2 consisted agricultural features while block 3 included agricultural input items. Variables on farmers' nutritional status and dietary patterns were entered in the final model. Standardized $\beta$ values were used to compare amount of variance accounted for by each predictor.

\section{Results}

Data on the recent previously grown major crops was collected thoroughly; among these crops, data on wheat productivity and required relevant parameters was available on 434 (96\%) farmers (malnourished: $n=214$, 95\%; well-nourished: $\mathrm{n}=220,97 \%$; $\mathrm{P}>0.05)$. Farmers flow and corresponding sample sizes are displayed by figure 1 .

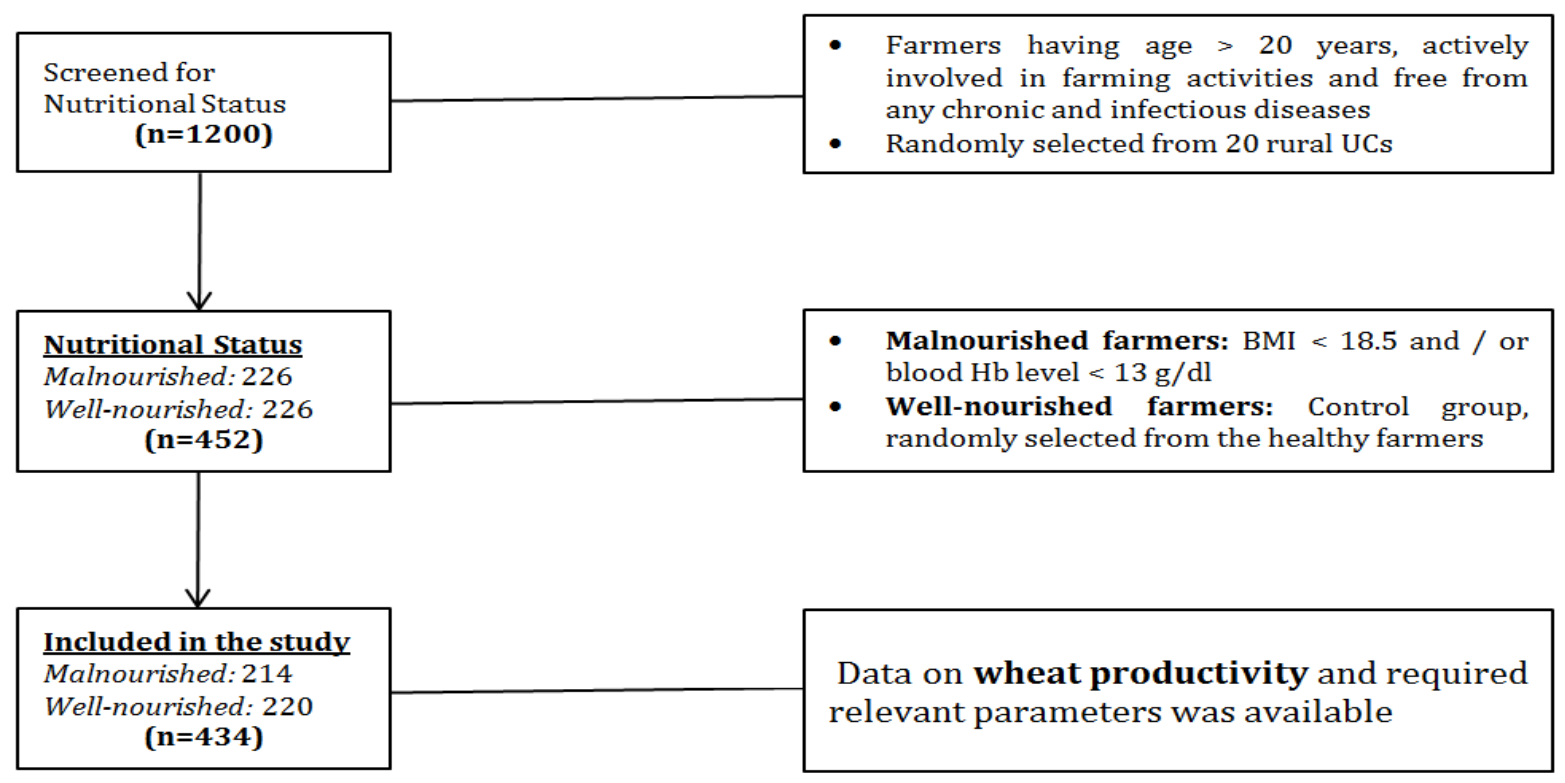

Figure 1 Flow chart describing sample size 
Table 1 depicts results on general socio-demographic, agricultural and nutritional characteristics by farmers' groups. No statistical differences were found in mean age and formal education among malnourished and wellnourished farmers $(\mathrm{P}>0.05)$. Similarly, no significant differences between groups were evident in 'income sources (other than agriculture)' ( $\mathrm{P}>0.05)$. Among the cohort, $42 \%, 25 \%$ and $33 \%$ of the farmers were owner, tenants and owner-cum-tenants respectively, with an average farm holding size of 4.1 acre. Crop rotation and intercropping was practiced by $56 \%$ and $41 \%$ farmers respectively. Only $10 \%$ of the farmers were found to cultivate the last wheat crop in inappropriate timing (either early or late). Similarly, only $6 \%$ of the farmers reported that weather disaster adversely affected the last wheat crop productivity. Among these agricultural characteristics, only difference in mean 'working hours per day' was evident between the farmers' groups; wellnourished farmers were on average found to be more involved in farm activities on daily basis than malnourished farmers $(\mathrm{P}<0.001)$.

As expected, malnourished farmers had lower mean weight, BMI, and blood $\mathrm{Hb}$ level than well-nourished farmers $(\mathrm{P}<0.001)$; however, no statistical difference in mean height was found among the groups $(\mathrm{P}>0.05)$. Results on dietary patterns showed that malnourished farmers were more likely than well-nourished farmers to have 'energy dense' patterns (55\% versus $45 \%$ ); however, difference between the groups was statistically marginal $(\mathrm{P}=0.058)$.

Table 2 shows results on average 'per acre inputs and yield' of the last wheat crop. All of the farmers used certified wheat seed for cultivation. Agricultural inputs (per acre) included seed rate, application of fertilizers (synthetic as well as organic), protection cost (such as cost on herbicide, weedicides and pesticide use), number of hired-labor days, number of irrigation and ploughing hours. The chemical (synthetic) fertilizers majorly applied were urea and Di Ammonium Phosphate (DAP). Apart from these fertilizers, other synthetic fertilizers that are not commonly used include micronutrients and Sulphate of Potash or Potassium Sulphate. No statistical differences were evident in means application of all agricultural inputs between the groups. On average, malnourished farmers were likely to utilize hired-labor for more days in comparison to well-nourished farmers; though the difference in mean hired-labor days was statistically marginal between the groups $(\mathrm{P}=0.054)$. Results on wheat productivity per acre show that a statistically significant difference in means wheat yield existed between the groups $(\mathrm{P}<0.05)$. Malnourished farmers reported lower yield comparing to the well-nourished.

Table 1 Socio-demographic, agricultural and nutritional characteristics by farmers' nutritional status

\begin{tabular}{|c|c|c|c|c|}
\hline \multirow{3}{*}{ Characteristics } & \multicolumn{4}{|c|}{ Mean \pm SD / N (\%) $)^{1}$} \\
\hline & \multirow{2}{*}{$\begin{array}{c}\text { Cohort } \\
(\mathrm{n}=434)\end{array}$} & \multicolumn{2}{|c|}{ Farmers' groups } & \multirow{2}{*}{$\begin{array}{c}\mathrm{P} \\
\text { values }\end{array}$} \\
\hline & & Malnourished $(n=214)$ & Well-nourished $(n=220)$ & \\
\hline \multicolumn{5}{|l|}{ Socio-demographic characteristics } \\
\hline Farmer age (year) & $41 \pm 7.9$ & $41 \pm 8$ & $40 \pm 8$ & NS \\
\hline Education (year) & $4 \pm 0.9$ & $4.1 \pm 1$ & $4 \pm 0.9$ & NS \\
\hline Income sources, Yes & $159(37 \%)$ & $77(48 \%)$ & $82(52 \%)$ & NS \\
\hline \multicolumn{5}{|l|}{ Agricultural characteristics } \\
\hline Farm holding size (Acre) & $4.1 \pm 1.2$ & $4.1 \pm 1.1$ & $4.0 \pm 1.2$ & NS \\
\hline Farming duration (year) & $19 \pm 5$ & $19.7 \pm 4.8$ & $18.8 \pm 5.3$ & NS \\
\hline \multicolumn{5}{|l|}{ Farm ownership status } \\
\hline Owner & $182(42 \%)$ & $88(48 \%)$ & $94(52 \%)$ & \\
\hline Tenants only & $108(25 \%)$ & $51(47 \%)$ & $57(53 \%)$ & NS \\
\hline Owners cum Tenants & $144(33 \%)$ & $75(52 \%)$ & $69(48 \%)$ & \\
\hline Crop rotation status, Yes & $245(56 \%)$ & $120(49 \%)$ & $125(51 \%)$ & NS \\
\hline Cropping status, Intercropping & $179(41 \%)$ & $85(47 \%)$ & $94(53 \%)$ & NS \\
\hline Working hours/day & $6.6 \pm 1.6$ & $6.1 \pm 1.4$ & $7.2 \pm 1.6$ & $<0.001$ \\
\hline Assistance in farming, No ${ }^{3}$ & $206(47 \%)$ & $108(52 \%)$ & $98(48 \%)$ & NS \\
\hline Sowing time, Early/Late & $42(10 \%)$ & $20(48 \%)$ & $22(52 \%)$ & NS \\
\hline Weather disaster, Yes & $28(6 \%)$ & $15(54 \%)$ & $13(46 \%)$ & NS \\
\hline \multicolumn{5}{|l|}{ Nutritional Status Indicators } \\
\hline Weight $(\mathrm{Kg})$ & $64 \pm 12.7$ & $60.2 \pm 12.3$ & $68.7 \pm 11.7$ & $<0.001$ \\
\hline Height (cm) & $168.2 \pm 6.9$ & $168.2 \pm 7.0$ & $168.3 \pm 6.8$ & NS \\
\hline BMI & $22.50 \pm 2.53$ & $21.46 \pm 2.49$ & $23.51 \pm 2.13$ & $<0.001$ \\
\hline $\mathrm{Hb}(\mathrm{g} / \mathrm{dl})$ & $13.3 \pm 1.6$ & $12.5 \pm 1.3$ & $14.0 \pm 1.5$ & $<0.001$ \\
\hline Dietary Pattern, Energy dense & $180(41.5 \%)$ & $99(55 \%)$ & $81(45 \%)$ & 0.058 \\
\hline
\end{tabular}


Table 2 Per Acre agricultural inputs and wheat production by farmers' nutritional status

\begin{tabular}{|c|c|c|c|c|}
\hline \multirow{3}{*}{ Characteristics } & \multicolumn{4}{|c|}{ Mean \pm SD / N (\%) } \\
\hline & \multirow{2}{*}{$\begin{array}{c}\text { Cohort } \\
(\mathrm{n}=434)\end{array}$} & \multicolumn{2}{|c|}{ Farmers' groups } & \multirow{2}{*}{$\begin{array}{c}\mathrm{P} \\
\text { values }^{2}\end{array}$} \\
\hline & & Malnourished $(n=214)$ & Well-nourished $(n=220)$ & \\
\hline Agricultural input items / Acre & & & & \\
\hline Seed rate $(\mathrm{kg})$ & $50.9 \pm 1.8$ & $50.9 \pm 2.0$ & $50.9 \pm 1.5$ & NS \\
\hline Urea $(\mathrm{kg})$ & $73 \pm 4.7$ & $72.9 \pm 4.3$ & $73.1 \pm 5.1$ & NS \\
\hline $\operatorname{DAP}(\mathrm{kg})^{3}$ & $47.8 \pm 2.9$ & $47.7 \pm 2.9$ & $47.8 \pm 2.8$ & NS \\
\hline Others fertilizers, No & $377(87 \%)$ & $184(49 \%)$ & $193(51 \%)$ & NS \\
\hline FYM (Ton) ${ }^{4}$ & $1.59 \pm 0.31$ & $1.61 \pm 0.32$ & $1.57 \pm 0.30$ & NS \\
\hline Labour (Number of days) & $8 \pm 1.7$ & $8.2 \pm 1.7$ & $7.4 \pm 1.6$ & 0.054 \\
\hline Protection cost per Acre (Rs.) ${ }^{5}$ & $999 \pm 55$ & $1004 \pm 58$ & $994 \pm 51$ & NS \\
\hline Number of irrigation application & $5 \pm 0.3$ & $5 \pm 0.3$ & $5 \pm 0.3$ & NS \\
\hline Ploughing hours & $4.1 \pm 1.1$ & $4.2 \pm 1.0$ & $4.0 \pm 1.3$ & NS \\
\hline Wheat Productivity, $000(\mathrm{~kg} \text { per Acre })^{6}$ & $1.55 \pm 0.09$ & $1.52 \pm 0.08$ & $1.57 \pm 0.10$ & $<0.05$ \\
\hline
\end{tabular}

Association between selected predictors (sociodemographic, agricultural and nutritional characteristics) and wheat yield per acre was evaluated using hierarchal regression analysis. The predictor variables were grouped based on qualitative similarity and entered as blocks in four steps. Table 3 depicts results of hierarchical regression analyses. The entire model accounted for $38.6 \%$ of the variance in wheat yield. Socio-demographic characteristics of the farmers significantly contributed to the regression model $-\mathrm{I}$ and accounted for $3.8 \%$ of the variance $(\mathrm{F}=5.738, \mathrm{P}<0.01)$. Introducing agricultural characteristics of the farmers (block - II) explained an additional $10.7 \%$ of variation in the outcome $(\Delta \mathrm{F}=5.847, \quad \mathrm{P}<0.001) ;$ as expected agricultural input items (block - III) explained more amount of variation (18.5\%) in wheat productivity $(\Delta \mathrm{F}=12.678, \mathrm{P}<0.001)$. Finally, addition of farmers' nutritional status and dietary pattern (block - IV) to the regression model explained an additional $5.5 \%$ of the variation in wheat production $(\Delta \mathrm{F}=18.392, \mathrm{P}<0.001)$. Overall, 11 predictors were identified in the final model that significantly explained variation in wheat production $(\mathrm{P}<0.05)$. In the final model, no socioeconomic predictor were significantly related to wheat yield $(\mathrm{P}>0.05)$. Among the agricultural characteristics, crop rotation was positive $(\beta=0.134, P<0.01)$, and inappropriate sowing time was negative $(\beta=-0.087, \mathrm{P}<0.05)$ predictor of wheat yield. Among per acre agricultural inputs, seed rate; application of urea, DAP and FYM; number of hired labor days; protection cost and ploughing hours were significantly positive predictors of wheat yield. Farmers' nutritional status as determined by blood hemoglobin level and BMI; and dietary patterns further increased variance in wheat yield. Malnourished farmers were more likely to report less yield in comparison to well-nourished farmers $(\beta=-$ $0.209, \quad \mathrm{P}<0.001)$. Similarly, farmers' 'energy dense' dietary pattern was found as mild negative predictor of wheat yield $(\beta=-0.100, P<0.05)$.

\section{Discussion and Conclusions}

Our main objective in this study was to find out whether indicators of nutritional status contributed significantly in predicting variance in wheat yield while controlling for several confounding factors. This was first study conducted in Pakistan to quantify the relationship between farmers' nutritional status and agricultural productivity. Being agricultural country, farmers' nutritional status in Pakistan plays an utmost role in determining food security at community level. Previously, a wide range of literature from around the globe demonstrated association of various measures of nutritional status and dietary diversity with work performance and productivity (Schultz, 2002; Ulimwengu, 2009).

Agricultural productivity as measured by wheat yield per acre in the current study was significant and responsive to variations in agricultural and nutritional characteristics of the farmers. Determinants, being identified in the final regression model that significantly explained variance in wheat yield included crop rotation, sowing time, fertilizers quantity and protection cost; and farmers' nutritional status and dietary patterns. Crop rotation and appropriate sowing timing were significant in explaining variance in wheat yield. These findings are not surprising; crop rotation provides improvement to agricultural yield by introducing nutrients back to the soil thus enhancing soil fertility as well as disturbing the habitat enough to reduce risk of weed growth and pest infestation (Liebman and Dyck, 1993). Similarly, sowing time is also a well-known determinant of crop yield. Timely sowing of wheat in the month of November results in improvement in yield because environmental conditions at this particular time favor seed germination as well as reduce risk of insect/pest attack and weed problems (Sharma et al., 2008). 
Table 3 Hierarchical multiple Regression of association between wheat yield, and farmers' socio-demographic, agricultural and nutritional characteristics

\begin{tabular}{|c|c|c|c|c|c|c|c|c|}
\hline \multirow{2}{*}{ Predictors } & \multicolumn{2}{|c|}{ Model-I } & \multicolumn{2}{|c|}{ Model-II } & \multicolumn{2}{|c|}{ Model-III } & \multicolumn{2}{|c|}{ Model-IV } \\
\hline & $\mathrm{B}(\mathrm{SE})$ & $\beta$ & $\mathrm{B}(\mathrm{SE})$ & $\beta$ & $\mathrm{B}(\mathrm{SE})$ & $\beta$ & $\mathrm{B}(\mathrm{SE})$ & $\beta$ \\
\hline \multicolumn{9}{|c|}{ Socio-demographic characteristics } \\
\hline Farmer age (year) & $0.035(0.01)$ & $0.118 *$ & $0.023(0.01)$ & 0.078 & $0.004(0.01)$ & 0.015 & $0.005(0.01)$ & 0.018 \\
\hline Education (year) & $0.277(0.11)$ & $0.117 *$ & $0.180(0.11)$ & 0.076 & $0.144(0.10)$ & 0.061 & $0.186(0.09)$ & 0.079 \\
\hline Income sources ${ }^{1}$ & $-0.555(0.23)$ & $-0.115^{*}$ & $-0.429(0.23)$ & -0.089 & $-0.289(0.21)$ & -0.060 & $-0.313(0.20)$ & -0.065 \\
\hline \multicolumn{9}{|c|}{ Agricultural characteristics } \\
\hline Farm holding size ${ }^{2}$ & & & $0.436(0.21)$ & $0.093 *$ & $0.265(0.19)$ & 0.057 & $0.292(0.19)$ & 0.063 \\
\hline Farming duration (year) & & & $0.040(0.02)$ & 0.087 & $0.024(0.02)$ & 0.052 & $0.026(0.02)$ & 0.057 \\
\hline LO (dummy-I $)^{3}$ & & & $-0.203(0.27)$ & -0.038 & $-0.134(0.24)$ & -0.025 & $-0.192(0.23)$ & -0.036 \\
\hline LO (dummy-II) ${ }^{4}$ & & & $0.508(0.24)$ & $0.103 *$ & $0.390(0.23)$ & 0.079 & $0.300(0.22)$ & 0.061 \\
\hline Crop rotation status ${ }^{5}$ & & & $0.968(0.22)$ & $0.207 * * *$ & $0.643(0.20)$ & $0.137 * *$ & $0.628(0.19)$ & $0.134 * *$ \\
\hline Cropping status $^{6}$ & & & $-0.259(0.22)$ & -0.055 & $-0.397(0.20)$ & $-0.085 *$ & $-0.369(0.19)$ & -0.078 \\
\hline $\begin{array}{l}\text { Family assistance in } \\
\text { farming (No) }\end{array}$ & & & $-0.470(0.21)$ & $-0.101 *$ & $-0.398(0.19)$ & $-0.086^{*}$ & $-0.360(0.19)$ & -0.077 \\
\hline Sowing time ${ }^{7}$ & & & $-0.529(0.34)$ & -0.072 & $-0.596(0.31)$ & -0.081 & $-0.640(0.30)$ & $-0.087 *$ \\
\hline WRD & & & $-0.601(0.43)$ & -0.064 & $-0.591(0.39)$ & -0.063 & $-0.505(0.38)$ & -0.053 \\
\hline \multicolumn{9}{|c|}{ Agricultural input items (Per Acre) } \\
\hline Seed rate $(\mathrm{kg})$ & & & & & $0.175(0.05)$ & $0.134 * *$ & $0.163(0.05)$ & $0.125 * *$ \\
\hline Urea $(\mathrm{kg})$ & & & & & $0.087(0.02)$ & $0.176^{* * *}$ & $0.079(0.02)$ & $0.160 * * *$ \\
\hline $\mathrm{DAP}(\mathrm{kg})$ & & & & & $0.124(0.03)$ & $0.154 * * *$ & $0.128(0.03)$ & $0.161 * * *$ \\
\hline Others fertilizers $^{8}$ & & & & & $-0.164(0.21)$ & -0.033 & $-0.160(0.20)$ & -0.032 \\
\hline FYM (Ton) & & & & & $0.845(0.32)$ & $0.114 * *$ & $0.958(0.30)$ & $0.129 * *$ \\
\hline Labour (No. of days) & & & & & $0.238(0.06)$ & $0.176 * * *$ & $0.261(0.05)$ & $0.194 * * *$ \\
\hline Protection cost & & & & & $0.005(0.002)$ & $0.120 * *$ & $0.006(0.002)$ & $0.147 * * *$ \\
\hline No. of irrigation app. & & & & & $0.418(0.26)$ & 0.067 & $0.310(0.25)$ & 0.050 \\
\hline Ploughing hours & & & & & $0.337(0.09)$ & $0.163 * * *$ & $0.291(0.08)$ & $0.141 * *$ \\
\hline \multicolumn{9}{|c|}{ Nutritional Status indicators } \\
\hline Nutritional Status ${ }^{9}$ & & & & & & & $-0.969(0.19)$ & $-0.209 * * *$ \\
\hline Dietary Pattern $^{10}$ & & & & & & & $-0.472(0.19)$ & $-0.100^{*}$ \\
\hline \multicolumn{9}{|l|}{ Summary Statistics: } \\
\hline & $\mathrm{R}^{2}=0.038$ & & $\mathrm{R}^{2}=0.145$ & & $\mathrm{R}^{2}=0.331$ & & $\mathrm{R}^{2}=0.386$ & \\
\hline & $\mathrm{F}=5.738(\mathrm{p}<0$ & & $\Delta \mathrm{R}^{2}=0.107$ & & $\Delta \mathrm{R}^{2}=0.185$ & & $\Delta \mathrm{R}^{2}=0.055$ & \\
\hline & & & $\Delta \mathrm{F}=5.847(\mathrm{p}$ & $0.001)$ & $\Delta \mathrm{F}=12.678(\mathrm{p}$ & $0.001)$ & $\Delta \mathrm{F}=18.392(\mathrm{p}$ & $0.001)$ \\
\hline
\end{tabular}

LO: Land ownership; WRD: Weather related disasters; ${ }^{1}$ Regular income sources other than agriculture (Yes versus No); ${ }^{2}$ Farm holding size $(<4$ Acre versus > 4 Acre) ${ }^{3}$ Tenant versus Owners ${ }^{4}$ Tenant cum owners' versus Owners; ${ }^{5}$ Crop rotation (Yes versus No) ${ }^{6}$ Intercropping versus Sole cropping; ${ }^{7}$ sowing time (early / late sowing versus appropriate timing of sowing); ${ }^{8}$ including micronutrient \& SOP or Sulphate of Potash (No versus Yes); ${ }^{9}$ Nutritional Status of the farmers (Malnourished versus Well-nourished); ${ }^{10}$ Dietary Pattern of the farmers (Energy dense versus Nutrient-rich); B $=$ unstandardized coefficients or regression estimate, $\mathrm{SE}=$ Standard Error of the estimate, $\beta=$ standardized coefficient; $* \mathrm{P}<0.05 * * \mathrm{P}<0.01 * * * \mathrm{P}<0.001$

In accordance to our expectation, per acre agricultural input items played crucial role in determining variation in wheat yield. Balanced application of inputs enhance yield, crop quality and farm income. Apart from high yielding variety, optimum seed rate as well as distribution of plants is also essential for maximum yield (Wood et al., 2003; Hiltbrunner et al., 2007). Similarly, other essential inputs such as organic and inorganic fertilizers; protection inputs and irrigation also play key roles in achieving the phenomenal increase in production as frequently reported in the literature (Mosier and Syers, 2004; Mueller et al., 2012; Ashraf et al., 2014; Petit et al., 2015). Nitrogen containing industrially produced fertilizers such as Urea and DAP, are significant to achieve high wheat yield. Crop production may be intensively constrained by application of inappropriate amount of synthetic fertilizers. Improper amount of fertilizers can restrict the provision of nutrients to the crop, which ultimately effect the plant growth and thus finally have negative impact on yield (Bameri et al., 2012). Beside synthetic fertilizers, farmyard manure (FYM) is also considered as an important source of nutrients that can play significant role in increasing yield by improving physical, chemical and biological properties of soil (Franzluebbers and Stuedemann, 2008). In Pakistan, inorganic fertilizers are costly; therefore small-scale farmers have usually either limited accessibility or synthetic fertilizers cannot be applied to the crops with recommended amount. Farmers can easily manage to prepare FYM in their farms; its use is commonly in practice by farmers in Pakistan.

Among the anthropometric measurements, means height of the group were statistically not different. Height is a good indicator of long-run nutritional status while other anthropometric measurements such as BMI as well as blood $\mathrm{Hb}$ level are strongly related to current nutritional status. Our findings suggest that farmers' groups were different in current nutrition status which could be improved by proper and appropriate intervention. On the other hand, though statistically nonsignificant, malnourished farmers were more likely to have 'energy dense' dietary pattern in comparison to wellnourished farmers. These differences in nutritional and dietary characteristics among the groups are important in term of farmers' health benefits. There were no 
differences in socio-economic characteristics among the farmers' groups. Similarly, no differences were evident among the groups in agricultural characteristics except for working hours per day. Malnourished farmers were on average less likely to be physically involved in farm activities in comparison to well-nourished farmers. Less physical involvement of malnourished farmers in the farming activities might result in higher number of hiredlabor days per acre in comparison to well-nourished farmers. This variation in labor input among the groups may lead to difference in net income derived from wheat yield. These findings explain the overall importance of farmers' health that may determine both agricultural productivity and net income. Health and nutrition, being basic components of human capital (Forbes et al., 2010), has been recognized in economic literature as sources of economic growth (Deaton, 2003; Bloom et al., 2004).

Previously, association between different indicators of nutrition status and work outputs as well as productivity has been reported. Low BMI was associated with an increased risk of morbidity and therefore has negative impact on work capacity and productivity (Thomas and Strauss, 1997). Similarly, strong causal relationships between all levels of iron deficiency and voluntary physical activity have been reported in both animal and human based studies (Untoro et al., 1998; Haas and Brownlie, 2001). In current study, wheat yield was significantly and independently related with farmers' nutritional status, being evaluated on the basis of both anthropometric (body mass index) and biochemical (blood hemoglobin level) indices. Health as a capital good can either improve or reduce human productive ability through different ways. Cole (2006) reported that farmers' poor health status as manifested by intense muscular fatigue and exhaustion resulted in frequent absentee from work. Poor nutritional status was frequently reported to be negatively related with work outputs in both farmers and workers from other different professions (Schultz, 2003). In developing countries, farm work is mostly physically demanding, particularly in small scale farming where farmers are intensively involved in ploughing, sowing, irrigation, crop protection and harvesting. Additionally, previous research literature concluded that the links between agriculture and health are bidirectional (Hawkes and Ruel, 2006; Asenso-Okyere et al., 2011; Fan and Pandya-Lorch, 2012): agriculture influences health and vice versa. Low agricultural productivity may lead to low income that could result in limited access to resources determining quality of life such as food and nutrition, medicine and other health facilities. On the other hand, malnutrition and poor health has been frequently reported to be associated with less work capacity and productivity (Ajani and Ugwu, 2008; Ulimwengu, 2009; Egbetokun et al., 2012).

The only limitation of the study is the reliance on selfreported dietary data using food frequency questionnaire (FFQ). However, the FFQ contained dietary items commonly consumed in the study area. Our study has certain strengths. This is the first large longitudinal and fully-funded study in Pakistan to investigate association between farmers' nutrition status and agricultural yield; sample size for screening of nutrition status was pretty large as well as both malnourished and well-nourished groups were drawn from the same study area representing a fairly homogeneous farming population. Agriculture being the primary livelihood source, all of the study subjects were intensively involved in farming activities. Nutritional status was assessed using physical and biochemical measurements; these criteria are wellrecommended and frequently used previously in studies on health, work capacity, productivity and income.

The study findings reaffirmed the importance of farmers' nutritional status in predicting wheat yield. Based on these findings, it is strongly recommended to prioritize, particularly farmers' health in all policies to promote agricultural productivity and ensure food security.

\section{Competing interests}

The authors declare that they have no competing interest.

\section{Acknowledgement:}

We acknowledge financial and logistic support given by the Pakistan Agricultural Research Council, Islamabad - Government of Pakistan in the completion of the study. We are particularly grateful to the local support / welfare organizations (LSOs) for providing basic detailed information about the farming community.

\section{References}

Ajani OIY, Ugwu PC. 2008. Impact of adverse health on agricultural productivity of farmers in Kainji Basin, North Central Nigeria using a stochastic production frontier approach. Trends in Agricultural Economics, 1 (1): 1-7.

Asenso-Okyere K, Chiang C, Thangata P, Andam KS. 2011. The Interaction between Health and Farm Labor Productivity in Africa. Food Policy Report. International Food Policy Research Institute (IFPRI). Washington DC, USA. Available online: http://addis2011.ifpri.info/files/2011/10/The-Interactionbetween-Health-and-Farm-Labor-Productivity-in-Africa1.pdf [Accessed 6th March 2016]

Ashraf VS, Mousavi SJ, Abbaspour KC, Srinivasan R, Yang H. 2014. Analyses of the impact of climate change on water resources components, drought and wheat yield in semiarid regions: Karkheh River Basin in Iran. Hydrological Processes, 28 (4): 2018-2032.

Badiane O, Ulimwengu J. 2009. The growth-poverty convergence agenda: Optimizing social expenditures to maximize their impact on agricultural labor productivity, growth, and poverty reduction in Africa (Vol. 906). International Food Policy Research Institute (IFPRI). Washington DC, USA.

Bameri M, Abdolshahi R, Mohammadi-Nejad G, Yousefi K, Tabatabaie SM. 2012. Effect of different microelement treatment on wheat (Triticum aestivum) growth and yield. International Research Journal of Applied and Basic Sciences, 3: 219-223.

Bartlett MS. 1950. Tests of significance in factor analysis. British Journal of Mathematical \& Statistical Psychology, 3 (2): 77-85.

Bloom DE. Canning D. Sevilla J. 2004. The effect of health on economic growth: A production function approach. World Development 32 (1): 1-13. 
Chen A, Seidl-Friedman J. 1988. HemoCue System for Hemoglobin Measurement. American Journal of Clinical Pathology, 90: 302305.

Cole D. 2006. Occupational health hazards of agriculture: understanding the links between agriculture and health (No. 13). International Food Policy Research Institute (IFPRI). Washington DC, USA.

Croppenstedt A, Muller C. 2000. The impact of farmers' health and nutritional status on their productivity and efficiency: Evidence from Ethiopia. Economic Development and Cultural Change, 48 (3): 475-502.

Deaton A. 2003. Health, Inequality, and Economic Development. Journal of Economic Literature, 41: 113-158.

Egbetokun OA. Ajijola S. Omonona BT. Omidele MA. 2012. Farmers' Health And Technical Efficiency In Osun State, Nigeria. International Journal of Food Sciences and Nutrition, 1 (1): 13-30.

Fan S. Pandya-Lorch R. 2012. Reshaping agriculture for nutrition and health. International Food Policy Research Institute (IFPRI). Washington DC, USA.

Forbes M. Barker A. Turner S. 2010. The effects of education and health on wages and productivity. Productivity Commission. Retrieved from: http://www.pc.gov.au/research/supporting/ education-health-effects-wages/education-health-effectswages.pdf [Accessed 20th March 2016]

Franzluebbers AJ, Stuedemann JA. 2008. Early response of soil organic fractions to tillage and integrated crop-livestock production. Soil Science Society of America Journal, 72 (3) 613-625.

Haas JD, Brownlie T. 2001. Iron deficiency and reduced work capacity: A critical review of the research to determine a causal relationship. Journal of Nutrition, 131 (2): 676S-690S.

Hawkes C, Ruel MT. 2006. Overview: Understanding the links between agriculture and health. International Food Policy Research Institute (IFPRI). Washington DC, USA.

Hiltbrunner J, Streit B, Liedgens M. 2007. Are seeding densities an opportunity to increase grain yield of winter wheat in a living mulch of white clover? Field Crops Research, 102 (3): 163-171.

Hoddinott J, Maluccio JA, Behrman JR, Flores R, Martorell R. 2008. Effect of a nutrition intervention during early childhood on economic productivity in Guatemalan adults. The Lancet, 371 (9610): 411-416.

Kim JO, Mueller CW. 1978. Factor analysis: Statistical methods and practical issues. Newbury Park, CA: Sage.

Kutner MH, Nachtsheim C. Neter J. 2004. Applied linear regression models. McGraw-Hill/Irwin.

Liebman M, Dyck E. 1993. Crop rotation and intercropping strategies for weed management. Ecological Applications, 3: 92-122.

Loureiro ML. 2009. Farmers' health and agricultural productivity. Agricultural Economics, 40: 381-388.
Mosier A, Syers JK. 2004. Agriculture and the nitrogen cycle: Assessing the impacts of fertilizer use on food production and the environment. Scope- 65. Island Press. London.

Mueller ND, Gerber JS, Johnston M, Ray DK, Ramankutty N, Foley JA. 2012. Closing yield gaps through nutrient and water management. Nature, 490: 254-257.

National Nutrition Survey (NNS). 2011. Report, Nutrition Division, National Institute of Health, Islamabad, Government of Pakistan. Retrieved from: https://www.humanitarianresponse. info/system/files/documents/files/59_National\%20Nutrition\%20 Survey-2011.pdf_[Accessed 9th March 2016].

Pakistan Economic Survey, 2010- 2011. Government of Pakistan, Finance Division, Economic Advisor's Wing, Islamabad. Retrieved from: http://www.finance.gov.pk/survey/chapter_11/ highlights.pdf [Accessed 17th February 2016]]

Pakistan Economic Survey, 2014- 2015. Government of Pakistan, Finance Division, Economic Advisor's Wing, Islamabad. Retrieved from: http://www.finance.gov.pk/survey/chapters_15/ Highlights.pdf [Accessed 17th February 20 16]]

Petit S, Munier-Jolain N, Bretagnolle V, Bockstaller C, Gaba S, Cordeau S, Lechenet M, Mézière D, Colbach N. 2015. Ecological intensification through pesticide reduction: weed control, weed biodiversity and sustainability in arable farming. Environmental Management, 56 (5): 1078-1090.

Schultz TP. 2002. Wage gains associated with height as a form of health human capital. American Economic Review, 92: 349353.

Schultz TP. 2003. Wage rentals for reproducible human capital: evidence from Ghana and the Ivory Coast. Economics \& Human Biology, 1 (3): 331-366.

Sharma DL, D'Antuono MF, Anderson WK, Shackley BJ, ZaicouKunesch CM, Amjad M. 2008. Variability of optimum sowing time for wheat yield in Western Australia. Crop \& Pasture Science, 59 (10): 958-970.

Thomas D, Strauss J. 1997. Health and wages: Evidence on men and women in urban Brazil Journal of Econometrics, 77 (1): 159185.

Ulimwengu J. 2009. Farmers' health and agricultural productivity in rural Ethiopia. A Stochastic Production Frontier Approach. International Food Policy Research Institute (IFPRI). Washington DC, USA.

Untoro J, Gross R, Schultink W, Sediaoetama D. 1998. The association between BMI and haemoglobin and work productivity among Indonesian female factory workers. European Journal of Clinical Nutrition, 52 (2): 131-135.

Wood GA, Welsh JP, Godwin RJ, Taylor JC, Earl R, Knight, SM. 2003. Real-time measures of canopy size as a basis for spatially varying nitrogen applications to winter wheat sown at different seed rates. Biosystems Engineering, 84 (4): 513-531 